Anna Wiśniewska-Grabarczyk*

Uniwersytet Łódzki

https://orcid.org/0000-0002-3005-200X

\title{
Konkurs na recenzję cenzorską powieści Wandy Wasilewskiej Rzeki płoną. Materiał archiwalny z poufnego biuletynu dla cenzorów z roku $1952^{1}$
}

Streszczenie: W sierpniu 1952 roku na łamach poufnego biuletynu Głównego Urzędu Kontroli Prasy, Publikacji i Widowisk ogłoszono konkurs na zbiorową, czyli pisaną przez pracowników danego urzędu cenzury, recenzję powieści Wandy Wasilewskiej pod tytułem Rzeki płoną. Jurorzy docenili trzy prace, które opublikowano w listopadzie tego samego roku.

Wszystkie nagrodzone teksty napisano zgodnie z wymogami stawianymi recenzjom pisanym w urzędzie cenzury w okresie stalinowskim. Wyróżnione zespoły cenzorskie uwzględniły w ocenie realizację ideologiczną i realizację artystyczną utworu oraz dotychczasowe dokonania i postawę autora.

Słowa-klucze: cenzura w powojennej Polsce, cenzura literatury, poufne biuletyny urzędu cenzury, Wanda Wasilewska, GUKPPiW, materiał źródłowy.

Anna Wiśniewska-Grabarczyk - badaczka cenzury Polski Ludowej, krytyczka literacka, autorka trzech książek i kilkudziesięciu artykułów naukowych, popularnonaukowych, krytycznoliterackich i publicystycznych; publikowała m.in. w „The Polish Review”, „Zagadnieniach Rodzajów Literackich”, „Socjolingwistyce”, „Dziejach Najnowszych”.

1 Artykuł powstał jako część projektu grantowego pt. Powojenna literatura polska w świetle kryptotekstów (na podstawie biuletynów Gtównego Urzędu Kontroli Prasy, Publikacji i Widowisk z lat 1945-1956), finansowanego przez Narodowe Centrum Nauki (Preludium 12, DEC-2016/23/N/ HS2/01798, okres realizacji 2017-2020, kierownik: Anna Wiśniewska-Grabarczyk). 


\section{The competition for a censor review of Wanda Wasilewska's novel Rzeki płoną [Rivers on fire]. Archival material from a confidential bulletin for censors from 1952}

Summary: In August 1952, a confidential bulletin of the Main Office of Control of Press, Publications and Shows announced a competition for a collective, i.e. written by the employees of a certain Office of Control, review of a novel by Wanda Wasilewska entitled Rzeki płoną. The jury appreciated three papers that were published in November of the same year.

All awarded texts were written in accordance with the requirements set for reviews written in the censorship office during the Stalinist period. The censor teams took into account in their evaluation the ideological and artistic implementation of the work, as well as the author's previous achievements and attitude.

Key words: censorship in post-war Poland, censorship of literature, confidential bulletins of censorship office, Wanda Wasilewska, GUKPPiW, source materials.

\section{Biuletyny urzędu cenzury}

Musicie zrozumieć, że Biuletyn tym lepiej będzie spełniał swoje zadania, im bardziej będzie z wami związany ${ }^{1}$.

W okresie instytucjonalnej kontroli wolnego słowa, jaka miała miejsce w Polsce w latach 1944-1990, cenzorzy oceniali w zasadzie każdy tekst kultury, który miał się ukazać (z wyjątkiem oczywiście publikacji drugiego obiegu). Jak niełatwa to była sztuka, świadczy fakt, iż od początku istnienia Urzędu Kontroli funkcjonariusze narzekali na brak materiałów szkoleniowych, które stanowiłyby pomoc w ich codziennej praktyce. Zwierzchnicy starali się

1 Z krajowej odprawy w GUKP, „Biuletyn Informacyjno-Instrukcyjny”, nr 7, lipiec 1952, s. 15 (APG, WUKPPiW, sygn. 84). 
wychodzić naprzeciw tym oczekiwaniom, publikując szereg dokumentów o charakterze pomocniczym, na przykład „Listy Informacyjno-Instrukcyjne”, „Sygnały” oraz „Instrukcje”2.

Jedną z inicjatyw było także powołanie do życia wewnętrznego biuletynu urzędu cenzury, tj. poufnego czasopisma skierowanego przede wszystkim do funkcjonariuszy politycznych, jak w latach 50. nazywano cenzorów. Decyzja o rozpoczęciu wydawania biuletynu zapadła bardzo wcześnie, pierwszy numer pisma ukazał się już w czerwcu 1945 roku $^{3}$, jednak o tym, że praktyka cenzorska wymagała podstaw teoretycznych, przekonywano w biuletynach wielokrotnie także w późniejszych latach ${ }^{4}$.

Pismo wychodziło pod nazwą „Biuletyn Instrukcyjny”, „Biuletyn Informacyjno-Szkoleniowy”, „Biuletyn Szkoleniowy” oraz „Biuletyn Informacyjno-Instrukcyjny”. Od stycznia 1952 do lutego 1956 roku ukazywało się jako miesięcznik ${ }^{5}$, ale zachowane w archiwach dokumenty nie pozwalają potwierdzić takiej regularności przy wydawaniu pisma w innych latach ${ }^{6}$.

2 Zob. m.in. A. Wiśniewska-Grabarczyk, The censorship review in the Polish People's Republic as cryptotext, „The Polish Review” 2019, vol. 64, no. 1, s. 37-40.

3 „Biuletyn Instrukcyjny”, czerwiec 1945 (APG, WUKPPiW, sygn. 210). W artykule używam skrótów: APG - Archiwum Państwowe Gdańsk; WUKPPiW - Wojewódzki Urząd Kontroli Prasy, Publikacji i Widowisk.

Okoliczności powstania biuletynów omówiłam w artykule „, $O$ wyższy poziom pracy nad książkq" - biuletyny urzędu cenzury z lat 1945-1956 w perspektywie literaturoznawczej. Rekonesans, [w:] Cenzura w PRL. Analiza zjawiska, red. Z. Romek, K. Kamińska-Chełminiak, Oficyna Wydawnicza ASPRA-JR, Warszawa 2017, s. 65-67. Zob. także: D. Nałęcz, Główny Urząd Kontroli Prasy 1945-1949, Instytut Studiów Politycznych PAN, Warszawa 1994, seria: Dokumenty do Dziejów PRL, z. 6, s. 10.

4 Zob. m.in. Podwyższyć poziom naszej pracy, „Biuletyn Informacyjno-Instrukcyjny”, nr 1, styczeń 1952, s. 1-3 (APG, WUKPPiW, sygn. 100); Artykuł wstępny, „Biuletyn Informacyjno-Instrukcyjny", nr 1, styczeń 1953, s. 2-8 (APG, WUKPPiW, sygn. 19).

5 K. Budrowska, Wewnętrzne pismo cenzury. „Biuletyn Informacyjno-Instrukcyjny” w latach 1952-1955, [w:] tejże, Studia $i$ szkice o cenzurze w Polsce Ludowej w latach 40. i 50. XX wieku, Wydawnictwo UwB, Białystok, 2014, s. 95-106; „Biuletyn Informacyjno-Instrukcyjny”. Wybór dokumentów z 1955 r., red. K. Budrowska, M. Budnik, W. Gardocki, seria: Cenzura w PRL. Archiwalia, t. 3, Wydawnictwo UwB, Białystok 2018.

6 Sprzed 1952 r. i po 1956 r. udało się do tej pory znaleźć w archiwach zaledwie kilkanaście numerów; zob. m.in. A. Wiśniewska-Grabarczyk, Bulletins of the Polish censorship office from 1945 to 1956. A reconnaissance study, „Acta Universitatis Lodziensis. Folia Litteraria Polonica” 2019, issue 4, s. 312-315.

Już po złożeniu niniejszego artykułu znalazłam w Archiwum Państwowym w Poznaniu obszerną teczkę o tytule „Biuletyny Instrukcyjno-Szkoleniowe” 1941-1951 (APP, WUKPPiW, sygn. 4, s. 1-291). Wyniki badań nad zbiorem opublikuję wkrótce. 
W periodyku omawiano aktualne zagadnienia polityczne i kulturalne, prezentowano materiały na temat cenzury i działalności Urzędu Kontroli, ogłaszając artykuły odredakcyjne oraz artykuły z terenu - recenzje cenzorskie, sprawozdania, bilanse, listy nadsyłane przez zespoły cenzorskie lub konkretnych pracowników. Analizowano literaturę piękną oraz inne typy piśmiennictwa, w tym teksty naukowe i popularnonaukowe.

W miesięczniku przeważały teksty o charakterze instrukcyjnym i szkoleniowym, których zadaniem było pouczenie i wychowanie wzorowego pracownika politycznego. Bowiem jednym z najczęstszych zarzutów wysuwanych wobec cenzorów były ich niskie kompetencje zawodowe, a co za tym idzie, nieumiejętność właściwej oceny składanych do Urzędu Kontroli materiałów. Dlatego w ramach szkolenia Redakcja Biuletynu omawiała szereg złych i bardzo złych recenzji i decyzji cenzorskich, analizując popełnione w nich błędy i przedstawiając jedyną słuszną interpretację utworu.

Inaczej było w listopadzie 1952 roku, gdy opublikowano trzy niemal wzorcowe prace, wyróżnione w ogłoszonym wśród cenzorów konkursie na najlepszą zbiorową, czyli pisaną przez pracowników danego urzędu, recenzję książki Wandy Wasilewskiej pod tytułem Rzeki płonq?

\section{Jak napisać wzorcową recenzję cenzorską?}

Entuzjazm, z którym autorka wyraża się o człowieku radzieckim, o jego serdecznym, braterskim stosunku do Polaków sprawia, że książka jest trwałym wkładem w przyjaźń Polsko-Radziecką ${ }^{8}$.

Maria Lorber, ówczesna szefowa łódzkiego WUKPPiW i pomysłodawczyni akcji, miała nadzieję, iż wydarzenie stanie się dobrym sprawdzianem umie-

7 Trzy recenzje, „Biuletyn Informacyjno-Instrukcyjny”, nr 11, listopad 1952, s. 47-66 (APG, WUKPPiW, sygn. 72). Zob. także K. Budrowska, Od orderu do „zapisu”. Jak GUKPPiW oceniat pisarzy w latach 1952-1955?, [w:] Kariera pisarza w PRL-u, pod red. M. Budnik, K. Budrowskiej, E. Dąbrowicz, K. Kościewicz, seria: Badania Filologiczne nad cenzura PRL, t. 4, IBL PAN, Warszawa 2014, s. 83-84.

8 Trzy recenzje, dz. cyt., s. 62. 
jętności łączenia teorii z praktyką. W przesłanym do Redakcji Biuletynu liście zaproponowała, by przedmiotem cenzorskiej refleksji uczynić powieść Wandy Wasilewskiej pod tytułem Rzeki płona ${ }^{9}$. Tak też się stało, konkurs ogłoszono w numerze sierpniowym, a do rywalizacji zachęcał Dział Publikacji Nieperiodycznych GUKPPiW oraz Redakcja Biuletynu ${ }^{10}$.

Pomysł nie spotkał się jednak z wielkim entuzjazmem ze strony pracowników, gdyż recenzje zbiorowe nadesłały tylko cztery z szesnastu wówczas istniejących ośrodków terenowych - były to urzędy łódzki, poznański, katowicki i krakowski ${ }^{11}$. Być może dlatego już w numerze październikowym ogłoszono, iż do rywalizacji stanąć mogą także cenzorzy, którzy nadeślą swoje indywidualne recenzje. Poinformowano wówczas, że na zwycięzców czekają komplety wartościowych książek, a prace oceni komisja w składzie: Niereńska, Kupraszwili, Landsberg, Tajer i Michlewicz ${ }^{12}$.

Recenzje zbiorowe napływały do Redakcji Biuletynu do 25 września 1952 roku. W listopadzie opublikowano in extenso trzy zwycięskie prace zespołów z Poznania, Krakowa i Łodzi, uznając, iż kolektyw wielkopolski zasłużył na nagrodę główną ${ }^{13}$. W artykule poprzedzającym wyróżnione teksty uzasadniono werdykt komisji oceniającej oraz zrekapitulowano najważniejsze momenty recenzowanych opracowań ${ }^{14}$.

9 Konkurs na recenzję, „Biuletyn Informacyjno-Instrukcyjny”, nr 8, sierpień 1952, s. 41-42 (APG, WUKPPiW, sygn. 81). O Marii Lorber zob. m.in.: A.B. Cieśla, Mania - cenzorka z Ryk; http:// www.ryki-dawniej.com/yewish-ryki/zide-z-ryk-ve-svete/mania---cenzorka-z-ryk?tmpl= $\% 2$ Fsystem\%2Fapp\%2Ftemplates\%2Fprint\%2F\&showPrintDialog=1 (dostęp 31.01.2020); S. Redlich, Na rozdrożu. Żydzi w powojennej Łodzi 1945-1950, Wydawnictwo IPN, Łódź 2012, s. 52, 54, 106, 107, 200, 230.

10 Tamże, s. 42.

11 Dzial Listów, „Biuletyn Informacyjno-Instrukcyjny”, nr 9, wrzesień 1952, s. 48 -49 (APG, WUKPPiW, sygn. 78); Artykut wstepny, „Biuletyn Informacyjno-Instrukcyjny”, nr 1, styczeń 1953, s. 7 (APG, WUKPPiW, sygn. 19).

12 Komunikat o konkursie, „Biuletyn Informacyjno-Instrukcyjny”, nr 10, październik 1952, s. 48 (APG, WUKPPiW, sygn. 75).

13 O wynikach konkursu na recenzje powieści W. Wasilewskiej „Rzeki płoną”, „Biuletyn Informacyjno-Instrukcyjny", nr 11, listopad 1952, s. 43-47 (APG, WUKPPiW, sygn. 72); Trzy recenzje, dz. cyt., s. 47-66. Zob. także Il. 1 Zdjęcie pierwszych stron zwycięskiej recenzji cenzorskiej powieści Wandy Wasilewskiej pt. Rzeki płona.

14 O wynikach konkursu na recenzje powieści W. Wasilewskiej „Rzeki płonq”, dz. cyt., s. 43-47. 
W zasadzie nie napisano wprost, dlaczego przystano na propozycję łódzkiej cenzorki, by to właśnie powieść Wasilewskiej poddać konkursowym zmaganiom. Jednak na pewno duże znaczenie miało to, że autorka była postacią znaną i zasłużoną dla nowego porządku. Przypomnijmy, iż Wasilewska funkcjonowała jako pisarka i działaczka komunistyczna od wielu lat i miała ugruntowaną pozycję na scenie politycznej i literackiej. Mimo że po wojnie została w Kijowie, odnalazła się w strukturach państwowych ZSRR oraz w dyplomacji i działała prężnie poza granicami Polski, nie utraciła tutaj swoich wpływów i utrzymywała stały kontakt $\mathrm{z}$ krajem ${ }^{15}$.

$\mathrm{Z}$ pewnością także problematyka utworu odegrała istotną rolę w zaakceptowaniu propozycji Lorberowej. W zwycięskiej recenzji czytamy, iż Wasilewska jako pierwsza w literaturze polskiej miała sięgnąć „po kluczowy temat przyjaźni Polsko-Radzieckiej i początków Polski Ludowej”16. Rzeczywiście w roku 1952 były to nadal zagadnienia bardzo ważne.

Na wybór pozycji wpływ mogło mieć także to, że w 1952 roku Rzeki pło$n q$ zostały uhonorowane Nagrodą Stalina ${ }^{17}$, a cały cykl powieściowy Pieśn nad wodami, którego konkursowy utwór był częścią, cieszył się uznaniem krytyki i czytelników, o czym świadczą recenzje literackie ukazujące się $\mathrm{w}$ ówczesnej prasie oraz liczne wznowienia i przekłady ${ }^{18}$. Cenzorzy otrzy-

15 O Wasilewskiej piszą m.in. M. Forma, Wanda Wasilewska jako autorka literatury adresowanej do dzieci i młodzieży, „Zbliżenia Cywilizacyjne” 2016, z. 4, s. 60-77; A. Mrozik, , Komuniści (nie) maja ojczyzny...” Wanda Wasilewska jako polska (anty)bohaterka narodowa, ,Studia Litteraria et Historica" 2013, z. 2, s. 528-554; S. Koper, Kobiety wtadzy PRL, Wydawnictwo Czerwone i Czarne, Warszawa 2012, s. 35-37; M. Shore, Wanda Wasilewska. Mą̇ stanu, [w:] tejże, Kawior i popiót. Życie i śmierć pokolenia oczarowanych i rozczarowanych marksizmem, Świat Książki, Warszawa 2008, s. 204-206 i in.; Wanda Wasilewska we wspomnieniach, wybór, wstęp i oprac. E. Salwa-Syzdek, KiW, Warszawa 1982; E. Salwa-Syzdek, Działalność Wandy Wasilewskiej w latach drugiej wojny światowej, Wydawnictwo MON, Warszawa 1981; E. Syzdek, W jednym życiu tak wiele... Opowieść o Wandzie Wasilewskiej, Młodzieżowa Agencja Wydawnicza, Warszawa 1980; A. Ciołkosz, Wanda Wasilewska. Dwa szkice biograficzne, Polonia Book Fund, Londyn 1977; H. Zatorska, Wanda Wasilewska, WSiP, Warszawa 1976.

16 Trzy recenzje, s. 48.

17 J. Kuczawa, Bumerang stalinowskiej laureatki, „Orzeł Biały” [Londyn] 1952, nr 31/32, s. $6-7$; nr 34, s. $4-5$.

18 Wybrane części cyklu ukazywały się w wydaniach zbiorowych oraz we fragmentach, zob. m.in.: pierwsza część cyklu, Płomień na bagnach, ukazywała się kolejno w latach: 1940, 1941, 1948, 1949, 1953, 1954; druga część, Gwiazdy w jeziorze, w roku 1950, 1953 i 1954; natomiast Rzeki płona wydano w następujących latach: Wydawnictwo MON, Warszawa 1952; wyd. 2: tamże 1953, wyd. 3: tamże 1953; PIW, Warszawa 1954; Państwowe Wydawnictwo Literatury Pięknej, Wilno 1955; Wydawnictwo MON, Warszawa 1956 (seria Pisma zebrane, t. 4). 
mali zatem do oceny jedną z bardziej popularnych pozycji. Faktem jednak jest, iż podobnych książek powstawało wówczas wiele, dość wspomnieć Siostrzeńców ciotki Agaty Janiny Broniewskiej, z którą zresztą Wasilewska się przyjaźniła ${ }^{19}$.

Utwory te opisywały losy Polaków przebywających w czasie II wojny światowej na terenie ZSRR. W sposób tendencyjny ukazywały polaryzację postaw, przedstawiając z jednej strony Armię Krajową i jej „londyńskie agentury"20, a z drugiej żołnierzy I Dywizji Piechoty im. Tadeusza Kościuszki, którzy u boku wojsk Związku Radzieckiego „wyzwalali kraj spod okupacji”. Jednym $\mathrm{z}$ istotnych celów tego typu literatury było przekonanie czytelnika, iż pojałtański porządek geopolityczny, z tak zwanymi Ziemiami Odzyskanymi i zachodnią granicą na Odrze oraz ze wschodnią granicą wzdłuż Bugu i utratą Kresów na rzecz ZSRR (czego oczywiście nie nazywano w ten sposób) jest tak naprawdę powrotem do pierwotnych granic, w przypadku granicy zachodniej mówiono nawet o powrocie na „prastare ziemie piastowskie"21.

Wasilewska była zagorzałą orędowniczką koncepcji „Polski Krzywoustego", rozpościerającej się od Odry po Bug, i zgodnie z tą wizją opisywała losy „Polaków zabużańskich”. Jedną z bohaterek jej powieści była znana z poprzednich części trylogii Jadwiga Chorzyniakowa, deportowana w głąb ZSRR

O cyklu powieściowym pisał przywoływany w biuletynie Ryszard Matuszewski, Trylogia Wasilewskiej, „Nowa Kultura” 18.05.1952, nr 20, s. 2, 11; poza tym zob. także cykl artykułów Zbigniewa Wasilewskiego publikowanych na łamach „Życia Literackiego” o przedwojennej twórczości pisarki: O powieściach Wandy Wasilewskiej z 3.02.1952, nr 3, s. 4-5; Wieś w jarzmie. O powieściach Wandy Wasilewskiej z 30.03.1952, nr 7, s. 3, 7 oraz artykuły o trylogii: Pieśń nad wodami. O powieściach Wandy Wasilewskiej z 11.05.1952, nr 10, s. 5-6 (o pierwszej i drugiej części trylogii, tj. Płomień na bagnach, Gwiazdy w jeziorze); Pierwsza powieść o Pierwszej Armii z 25.05.1952, nr 11, s. 10-15 (o trzeciej części trylogii, tj. Rzeki płona); ponadto zob: H. Bereza, Wanda Wasilewska, „Płomień na bagnach”, „Gwiazdy w jeziorze”, „Rzeki płoną”, „Twórczość” 1953, nr 5, s. 181-188; J. Putrament, Wanda Wasilewska i rewolucyjny nurt literatury polskiej, [w:] tegoż, Na literackim froncie, „Czytelnik”, Warszawa 1953, s. 9-15.

19 M. Shore, Przyjaźń między kobietami, [w:] tejże, Kawior i popiót. Życie i śmierć pokolenia oczarowanych i rozczarowanych marksizmem, Świat Książki, Warszawa 2008, s. 155-160, 409 i in.

20 Trzy recenzje, dz. cyt., s. 53.

21 O cenzurowaniu tematyki kresowej zob. m.in. K. Budrowska, Cenzurowanie tematyki pogranicza w Polsce Ludowej w latach 1945-1956. Przeglad problematyki badań, „Studia Wschodniosłowiańskie" 2015, t. 15, s. 533-542. Zob. także: J. Szydłowska, Narracje pojałtańskiego Okcydentu. Literatura polska wobec pogranicza na przyktadzie Warmii i Mazur (1945-1989), Wydawnictwo UWM, Olsztyn 2013, s. 70; K. Gieba, Próba epopei. O narracjach założycielskich tzw. Ziem Odzyskanych, „Teksty Drugie”2015, z. 5, s. 321-335. 
córka polskiej obszarniczki, żona osadnika wojskowego na ziemiach zachodniej Ukrainy. To wystarczyło, by cenzorzy zwycięskiej recenzji potraktowali ją jako część „elementu polskiego, który na ziemiach Ukrainy i Białorusi stanowił podporę reżimu sanacyjnego"22. Na przykładzie Jadwigi autorka wnikliwie przedstawiła, jak to ujęto, ,swoisty problem ojczyzny [...] podobnie odczuwany przez miliony Polaków zabużańskich"23 oraz zrealizowała istotny z punktu widzenia poetyki socrealizmu motyw przemiany bohaterki i jej ideowego dorastania do bycia bojowniczką o socjalizm i lepszy świat ${ }^{24}$.

Przyjrzyjmy się zatem, jak wyglądały wzorcowe recenzje cenzorskie wzorcowej powieści.

\section{Trzy recenzje cenzorskie}

Najwięcej miejsca poświęcono realizacji ideologicznej utworu. Na uznanie zasłużyło, zgodne z ówczesną wykładnią przedstawienie wydarzeń, które doprowadziły do powstania nowej sytuacji geopolitycznej, pochwalono między innymi uwypuklenie „roli Związku Radzieckiego w wyzwoleniu świata od faszystowskiego barbarzyństwa oraz w powstaniu Polski Ludowej”25. Nie zabrakło także trafnych wedle komisji opisów działań zarówno obcych jak i rodzimych imperialistów, którzy starali się zdyskredytować i osłabić ZSRR i Polskę. Z dzisiejszej perspektywy szczególnie uderzające było docenienie Wasilewskiej za takie przedstawienie „sprawy” katyńskiej i powstania warszawskiego, które wedle cenzorów pomogło „czytelnikowi w obiektywnej ocenie tych wydarzeń" ${ }^{26}$. Jak obiektywne musiało to być ujęcie niech świadczy kłamliwa postawa Wasilewskiej tożsama z wydanym w lutym 1952 roku, a więc w roku ukazania się ocenianej powieści, stanowiskiem rządu Cyrankiewicza wobec działań amerykańskiej tak zwanej Specjalnej komisji Izby

22 Trzy recenzje, dz. cyt., s. 50.

23 Tamże, s. 53, zob. również s. 64.

24 Tamże, s. 50, 58.

25 O wynikach konkursu na recenzje powieści W. Wasilewskiej „,Rzeki płoną”, dz. cyt., s. 43.

26 Trzy recenzje, dz. cyt., s. 57, zob. także s. 63.

27 W. Wasilewska, Mord w Katyniu, [w:] Prawda o Katyniu, Związek Patriotów Polskich w ZSRR, Moskwa 1944, s. 5-7; M. Polak, Wanda Wasilewska o Katyniu. Przyczynek do poczty renegatów polskich II Wojny Światowej, „Mars. Problematyka i historia wojskowości. Studia i materiały" 2002, t. 12, s. 145-154. 
Reprezentantów dla sprawy katyńskiej ${ }^{27}$. W oświadczeniu Rządu RP czytamy, iż ,zbrodnia katyńska była ogniwem akcji hitlerowskiej, stanowiącej sobie za cel fizyczną eksterminację narodu polskiego, realizowanej konsekwentnie w okresie okupacji"28.

We wszystkich trzech recenzjach dość dobrze zbilansowano proporcje między oceną książki a streszczeniem fabuły. To musiało wpłynąć na decyzje komisji, gdyż zarzuty o to, że w ewaluacjach cenzorskich segment streszczający dominował nad oceniającym były na porządku dziennym ${ }^{29}$. W wyróżnionych pracach streszczeniu i charakterystyce postaci towarzyszyły zawsze elementy wartościujące. Tak było, na przykład przy okazji przedstawienia losów Chorzyniakowej, Rojkowej i Zabielskiego. Cenzorzy poznańscy ocenili, iż w przypadku postaci kobiecych problem przemian ideologicznych zarysowano „sugestywnie i trafnie pod względem artystycznym i politycznym" ${ }^{30}$, za wiarygodne uznano na przykład ukazanie, jak ,z Rojkowej - mieszczki grójeckiej rodzi się dzielna kobieta, matka synów-żołnierzy i bojowniczka o jutro swej ojczyzny"31, natomiast w przypadku Zabielskiego skrytykowano zbyt powierzchowne i „skokowe” zarysowanie jego ideowego zwrotu: „Powtarzamy - Zabielski mógł przejść taką niezwykle trudną drogę - należało to jednak w sposób przekonywujący uzasadnić" 32 (pisownia i podkr. oryg.).

Wyróżnione recenzje różniły się w ocenie poszczególnych rozwiązań fabularnych i wiarygodności postaci. Skrytykowana wyżej kreacja Zabielskiego została doceniona przez kolektyw łódzki, który dostrzegł w tym byłym sanacyjnym poruczniku niezwykle cenny przykład dla szeregu tych, którzy „nie mogli odnaleźć swego miejsca w społeczeństwie bojąc się swojej przeszłości lub wahając się zerwać z nią ostatecznie"33.

Różnice miały miejsce także w ocenie selekcji materiału, który posłużył za kanwę opowieści. Podkreślano, iż autorka starała się nie pominąć żadnego

28 Oświadczenie Rzadu RP, „Nowiny Rzeszowskie” 1-2.03.1952, nr 53, s. 1.

29 A. Wiśniewska-Grabarczyk, Segment streszczający recenzji cenzorskiej (na materiale GUKPPiW z roku 1950), „Socjolingwistyka” 2016, z. 1 (30), s. 277-288.

\footnotetext{
30 Trzy recenzje, dz. cyt., s. 51.

31 Tamże.

32 Tamże.

33 Tamże, s. 59.
} 
$\mathrm{z}$ istotnych wydarzeń, co nie było łatwe w kontekście burzliwej historii tamtego okresu. Jedynie cenzorzy krakowscy dostrzegli drobne uchybienia w tym zakresie, pisząc o ścierających się w powieści dwóch koncepcjach literackich. Wedle nich zawarty w książce:

[...] olbrzymi materiał epicki domagał się specyficznej formy powieściowej, w której dominowałyby czynniki perspektywy historycznej. Ponieważ jednak autorka znajdowała się w samym nurcie tworzenia się historii i brała w nim bezpośredni, aktywny udział, nie mogła zająć stanowiska beznamiętnego obserwatora i całą swoją pracę twórczą skierowała na tworzenie porywających obrazów, które jednak dość luźno są ze sobą związane, co zaważyło na konstrukcji powieścij3.

Oczywiście dobór i sposób ujęcia prezentowanych treści miał swoje uzasadnienie ideologiczne. Książka powinna przekonać niezdecydowanych i ugruntować w politycznej wierze już przekonanych, podobnie jak opisywana przez Wasilewską nowa moralność obywateli ZSRR, której zbawienny wpływ na „obałamuconych przez reakcję ludzi” ${ }^{35}$ autorka ukazywała na przykładzie tendencyjnie skonstruowanych losów swoich bohaterów.

$\mathrm{Z}$ aprobatą wypowiedziano się także o ogromnym ładunku liryczno-osobistym, z jakim Wasilewska opisywała wydarzenia, w których sama brała przecież czynny udział. Obszerny fragment zwycięskiej recenzji poświęcono na przedstawienie sylwetki pisarki-rewolucjonistki, osoby tak bardzo zasłużonej dla krzewienia komunistycznych ideałów. Doceniono jej działalność polityczną oraz literacką, podkreślając prekursorską rolę, jaką odegrała w implementacji realizmu socjalistycznego na grunt polski:

Wasilewską słusznie można uważać za pioniera realizmu socjalistycznego w naszej literaturze. Była pierwszą wśród polskich pisarzy, która zrozumiała ogromne znaczenie Rewolucji Październikowej dla losów ludzkości, a w szczególności dla Polski36.

34 Tamże, s. 65.

35 O wynikach konkursu na recenzje powieści W. Wasilewskiej „,Rzeki płoną”, dz. cyt., s. 44.

36 Trzy recenzje, dz. cyt., s. 47. 
W artykułach recenzyjnych przypominano koleje losu pisarki, podkreślając jej działania na rzecz szerzenia internacjonalizmu, czyli jednego ze sztandarowych haseł ideologii komunistycznej. Międzynarodowa solidarność proletariuszy i klas pracujących była bliska autorce od dawna, dzięki czemu jej twórczość także w okresie Polski sanacyjnej „mogła zagrzewać ludzi do walki z faszyzmem, z wszelkim wstecznictwem i niesprawiedliwością" ${ }^{37} \mathrm{w}$ nadziei na zwycięstwo nad ustrojem wyzysku nie tylko w kraju, ale i na całym świecie - jak pisał zespół poznański.

Istotne $\mathrm{z}$ propagandowego punktu widzenia było również informowanie w recenzjach o wielotysięcznych nakładach, jakie książki Wasilewskiej osiągały w Polsce Ludowej. Miało to pokazać rangę pisarki-rewolucjonistki.

Odwoływanie się do biografii i dokonań pisarza było jedną ze strategii cenzurowania, podobnie zresztą jak powoływanie się na autorytety z dziedziny, z czego skorzystano w materiale poprzedzającym prezentację wyróżnionych prac. Redakcja Biuletynu przytoczyła kilka fragmentów z artykułu Ryszarda Matuszewskiego, cenionego wówczas historyka i krytyka literatury, na przykład ten o „rozsadzaniu epickich ram powieści”38. Warto zaznaczyć, iż w momencie ukazania się recenzji Matuszewski był już zastępcą redaktora naczelnego „Nowej Kultury”, którą to funkcję sprawował od kwietnia 1950 do grudnia 1955 roku $^{39}$. W samych konkursowych recenzjach nie znajdziemy dokładnych cytatów z Matuszewskiego, lecz zespoły z pewnością znały zarówno ten jak i inne artykuły dotyczące powieści, na co wskazuje wiele podobnych w tych pracach sformułowań i ocen ${ }^{40}$.

W opisie działań zbrojnych i realiów dotyczących II wojny światowej zespoły cenzorskie operowały podobnymi środkami wyrazu jakie stosowano w wielu powstających wówczas ocenach książek o tej tematyce, na przykład

37 Tamże, s. 48; zob też s. 53.

38 R. Matuszewski, dz. cyt., s. 11.

39 Zob. m.in. J. Zawadzka [J. Z.], Matuszewski Ryszard, [w:] Współcześni polscy pisarze i badacze literatury. Stownik biobibliograficzny, t. 5: $L-M$, pod red. J. Czachowskiej, A. Szałagan, WSiP, Warszawa 1997, s. 327-331.

40 Zob. np. powieść Wasilewskiej jest „trwałym wkładem w przyjaźń polsko-radziecką" (Trzy recenzje, dz. cyt., s. 62 i „,cennym i trwałym wkładem w dzieło przyjaźni polsko-radzieckiej” (R. Matuszewski, dz. cyt., s. 2). 
„charakterystycznym dla nowomowy dychotomicznym podziałem rzeczywistości”41, z ostrym rozróżnieniem na „naszych” i „obcych”; nawet jeśli Wasilewska starała się zachować pozory obiektywizmu i przedstawić szersze spektrum, podział był bezdyskusyjny:

[...] autorka nie sięga do jednego środowiska Polaków w ZSRR, ale stara się przedstawić przekrojowo niejako całe społeczeństwo polskie od klasy robotniczej i jej działaczy poprzez drobnomieszczaństwo do przedstawicieli klas posiadających i wodzirejów sanacyjno-faszystowskich ${ }^{42}$.

Taki sposób ujęcia utrzymywał się zresztą także w książkach ukazujących powojnie, na przykład przy przedstawianiu żołnierzy Armii Krajowej przeciwstawiających się sowietyzacji Polski już po 1945 roku $^{43}$.

W trzech zwycięskich pracach dominowały pochwały, ale znalazły się także uwagi krytyczne, które jednak nie miały wpływu na końcową pozytywną ocenę książki.

Jeden z zarzutów wobec powieści dotyczył sposobu narracji oraz drobnych niekonsekwencji w portretowaniu psychologicznym bohaterów, szczególnie w obrazowaniu ich ideologicznych przemian. Kilka uwag na ten temat pojawiło się w recenzji poznańskiej, w której skrytykowano sposób przedstawienia wspominanego wyżej Zabielskiego i innego z bohaterów, Szuwary. Poza nimi wszystkie niemal postacie, nawet drugo- i trzecioplanowe, były wedle funkcjonariuszy ,pełne, wyraziste w rysunku, zindywidualizowane, z właściwymi tylko sobie cechami charakterystycznymi, przeżyciami wewnętrznymi, zaletami i wadami”" ${ }^{4}$. Natomiast w dwóch pozostałych recenzjach zwrócono uwagę, iż charakterystyka postaci „opiera się dość często na ich wewnętrznych monologach, podczas gdy bezpośrednia narracja lepiej prawdopodobnie

41 A. Wiśniewska-Grabarczyk, ,, Czytelnik” ocenzurowany. Literatura w kryptotekstach - recenzjach cenzorskich okresu stalinizmu (na materiale GUKPPiW z 1950 roku), Wydawnictwo IPN, Warszawa 2018, s. 38.

42 Trzy recenzje, dz. cyt., s. 48; zob. także s. 53-54, 58, 60-63.

43 Zob. m.in. M. Woźniak-Łabieniec, Rytuat w zwierciadle cenzury. Urząd Kontroli jako strażnik kultowego obrazu władzy w poczatkach Polski Ludowej, „Napis. Pismo poświęcone literaturze okolicznościowej i użytkowej” 2010, seria 16, s. 377-379.

44 Trzy recenzje, dz. cyt., s. 51-52. 
uwypukliłaby zdarzenia i przemiany niż rozmyślania bohaterów"45, na co uwagę zwrócił w swojej recenzji także Matuszewski ${ }^{46}$. Wedle zespołu łódzkiego i krakowskiego takie przechodzenie od realistycznych opisów do monologów wewnętrznych kłóciło się z założeniami realizmu socjalistycznego i mogło być wstępem do psychologizmu. Obawa zgłoszona przez funkcjonariuszy nie była bezpodstawna. Należy bowiem przypomnieć, iż właśnie w tamtym czasie psychologizm i poetyki nierealistyczne były na cenzurowanym, stanowiąc jeden z zarzutów, który mógł decydować o zatrzymaniu książki lub o konieczności wprowadzenia poprawek ${ }^{47}$. Mimo to jurorzy oceniający prace nie zgodzili się z wyrażoną przez dwa zespoły opinią, o wiele bardziej przypadła im do gustu ocena towarzyszy z Poznania, którzy wedle nich „lepiej zauważyli wyniki niepełnej narracji”" ${ }^{4}$, a mianowicie - zbyt fragmentaryczne opisy najlepszych przedstawicieli klasy robotniczej i niedostateczne przedstawienie roli komunistów polskich w akcji powieści. Mimo to doceniono i wymieniono kilka „niezapomnianych" scen, jak choćby tę ukazującą „generała Waltera nad brzegiem Wisły ostrzeliwanym przez hitlerowców, naprzeciw płonącej Warszawy"49.

Na korzyść zwycięskiej recenzji świadczyło także to, iż jej autorzy docenili jeszcze inny chwyt kompozycyjny Wasilewskiej, a mianowicie „wspaniałe sceny bojowe" ${ }^{50}$, o wielkim nasileniu dramatycznym. Docenił je także przywoływany po raz kolejny przez Redakcję Biuletynu Matuszewski, który pisał, iż mimo że nie było ich zbyt wiele, stanowiły one namiętny, żarliwy szkic, liryczny pamiętnik głęboko czującego serca ${ }^{51}$.

Jurorzy oceniający konkursowe prace nie zgodzili się natomiast $\mathrm{z}$ interpretacją przedstawioną przez zespół łódzki, który utyskiwał na to, że w niektórych fragmentach Wasilewska sprzeniewierzyła się realizmowi, że oddając głos zbyt wielu bohaterom, nie stworzyła jednego, spójnego,

45 O wynikach konkursu na recenzje powieści W. Wasilewskiej „Rzeki płoną”, dz. cyt., s. 45.

46 R. Matuszewski, dz. cyt., s. 11.

47 K. Budrowska, Literatura i pisarze wobec cenzury PRL. 1948-1958, Wydawnictwo UwB, Białystok 2009, s. 210.

48 O wynikach konkursu na recenzje powieści W. Wasilewskiej „Rzeki płoną”, dz. cyt., s. 45.

49 Trzy recenzje, dz. cyt., s. 52.

50 O wynikach konkursu na recenzje powieści W. Wasilewskiej „Rzeki płoną”, dz. cyt., s. 46.

51 Por. tamże oraz R. Matuszewski, dz. cyt., s. 11. 
rzeczywistego obrazu bitwy pod Lenino. W odpowiedzi na ten bezpodstawny, zdaniem komisji, zarzut, zacytowano odpowiedni fragment z Referatu sprawozdawczego XIX Zjazdu KPZR, w którym Gieorgij Malenkow, jeden z najbliższych współpracowników Stalina, mówił o kategorii typowości w sztuce, redefiniując i dostosowując pojęcie tak, by odpowiadało metodzie twórczej socrealizmu:

Typowe jest nie tylko to, co się spotyka najczęściej, lecz to, co najpełniej i z największą ostrością wyraża istotę danej siły społecznej. W ujęciu marksistowskoleninowskim to, co typowe, nie oznacza bynajmniej jakiejś średniej statystycznej. Typowość odpowiada istocie danego zjawiska społeczno-historycznego, nie jest zaś po prostu zjawiskiem najbardziej rozpowszechnionym, najczęściej się powtarzającym, powszednim. Świadome przejaskrawienie, wyostrzenie obrazu nie wyklucza typowości, lecz w pełniejszej mierze ujawnia ją i podkreśla. Typowość stanowi podstawową sferę przejawiania się partyjności w sztuce realistycznej. Problem typowości jest zawsze problemem politycznym ${ }^{52}$.

Powoływanie się na wysokich urzędników państwowych, niekoniecznie specjalistów w danej dziedzinie, miało oczywiście znaczenie propagandowe i ucinało w pewnym sensie dalsze dyskusje nad podjętym zagadnieniem. Warto zaznaczyć, iż w tym wypadku sięgnięto po referat wygłoszony niespełna miesiąc wcześniej, gdyż XIX Zjazd KPZR, która powstała właśnie wtedy w miejsce WKP(b), odbywał się między 5 a 14 października 1952 roku. Miało to oczywiście swoje głębokie uzasadnienie propagandowe, ale także szkoleniowe - dzięki temu, że Redakcja posiłkowała się najświeższymi materiałami, cenzorzy mieli poczucie, że nadążają za zachodzącymi zmianami. Tym bardziej że samo przemówienie było szeroko dyskutowane

52 O wynikach konkursu na recenzje powieści W. Wasilewskiej „Rzeki płoną”, dz. cyt., s. 46. Referat sprawozdawczy na XIX Zjeździe Partii o działalności KC WKP(b) został wygłoszony na pierwszym od wybuchu II wojny światowej Zjeździe KPZR oraz pierwszym od objęcia przez Stalina przywództwa, na którym to nie on go wygłaszał.

O kategorii typowości w literaturze zob. m.in. W. Tomasik, Realizm Socjalistyczny. Zasada typowości, [w:] Słowo o socrealizmie. Szkice, Wydawnictwo Wyższej Szkoły Pedagogicznej w Bydgoszczy, Bydgoszcz 1993, s. 7-8; H. Markiewicz, O typowości w literaturze. Z historii problemu, „Pamiętnik Literacki” 1957, z. 1 (48), s. 46-82; A. Wasilewski, O kilku problemach typowości, „Nowa Kultura” 1953, nr 34, s. 1-2. 
na łamach ówczesnej prasy i zostało wydane nakładem Książki i Wiedzy jeszcze w tym samym roku ${ }^{53}$.

Zauważmy na koniec, że przywołanie kategorii „typowości” było w tym momencie, czyli w listopadzie 1952 roku, wysoce uzasadnione. Od stycznia bowiem toczyła się w prasie dyskusja na temat schematyzmu w literaturze, którą otworzył artykuł Ludwika Flaszena w „Życiu Literackim”54. Według krytyka to właśnie błędne rozumienie postulatu „typowości” było źródłem schematyzmu, od którego starano się coraz częściej odchodzić.

$* * *$

Jak pisałam, konkurs na recenzję cenzorską powieści Wasilewskiej został przyjęty z dużą rezerwą. Z szesnastu urzędów cenzury tylko cztery nadesłały swoje propozycje, spośród których wyróżniono i opublikowano w biuletynie trzy. W zwycięskich pracach uwzględniono te elementy, które powinny się znaleźć w każdej cenzorskiej ewaluacji - przede wszystkim realizację ideologiczną oraz problematykę utworu, ponadto jego wartość artystyczną oraz wychowawczo-edukacyjną. Omówiono także dotychczasowe dokonania i postawę autora oraz okoliczności powstania dzieła. We wszystkich recenzjach starano się także o zrównoważenie pozytywnej oceny dzieła uwagami krytycznymi.

Wedle jury najwięcej trafnych obserwacji oraz najmniej błędów popełnił zespół poznański i to on zdał na szóstkę egzamin z pisania recenzji. Dodatkowym plusem było to, iż recenzja poznańska wyróżniała się „ładnym językiem i staranną formą opracowania" 55 .

53 Zob. m.in. G.M. Malenkow, Referat sprawozdawczy na XIX Zjeździe Partii o działalności KC WKP(b), KiW, Warszawa 1952; J. Putrament, Idea staje się życiem, „Nowa Kultura” 5.10.1952, nr 40, s. 1-2; XIX Zjazd KPZR. O sprawach kultury i sztuki, „Życie Literackie” 26.10.1952, nr 22, s. 2, 15.

54 L. Flaszen, Nowy Zoil, czyli o schematyzmie, „Życie Literackie” 1952, nr 1, s. 3-4.

55 O wynikach konkursu na recenzje powieści W. Wasilewskiej „Rzeki płoną”, dz. cyt., s. 47. 


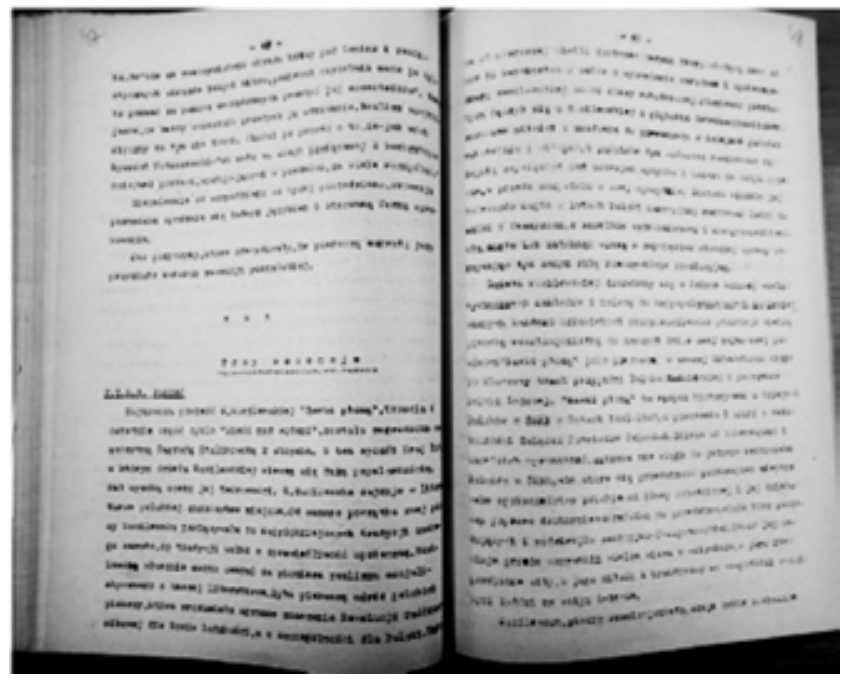

Il. 1. Zdjęcie pierwszych stron zwycięskiej recenzji cenzorskiej powieści Wandy Wasilewskiej pod tytułem Rzeki płona (Trzy recenzje, dz. cyt., s. 47-48).

\section{Bibliografia}

\section{Materiał archiwalny}

APG, WUKPPiW, sygn. 19.

APG, WUKPPiW, sygn. 72.

APG, WUKPPiW, sygn. 75.

APG, WUKPPiW, sygn. 78.

APG, WUKPPiW, sygn. 81.

APG, WUKPPiW, sygn. 84.

APG, WUKPPiW, sygn. 100.

APG, WUKPPiW, sygn. 210.

APP, WUKPPiW, sygn. 4. 
Bereza H., Wanda Wasilewska, „Płomień na bagnach", "Gwiazdy w jeziorze”, „Rzeki płoną", „Twórczość" 1953, nr 5, s. 181-188.

„Biuletyn Informacyjno-Instrukcyjny". Wybór dokumentów z 1955 r., red. K. Budrowska, M. Budnik, W. Gardocki, seria: Cenzura w PRL. Archiwalia, t. 3, Wydawnictwo UwB, Białystok 2018.

Budrowska K., Literatura i pisarze wobec cenzury PRL. 1948-1958, Wydawnictwo UwB, Białystok 2009.

Budrowska K., Od orderu do "zapisu”. Jak GUKPPiW oceniał pisarzy w latach 19521955?, [w:] Kariera pisarza w PRL-u, pod red. M. Budnik, K. Budrowskiej, E. Dąbrowicz, K. Kościewicz, seria: Badania Filologiczne nad cenzurą PRL, t. 4, IBL PAN, Warszawa 2014, s. 78-95.

Budrowska K., Wewnętrzne pismo cenzury. „Biuletyn Informacyjno-Instrukcyjny" w latach 1952-1955, [w:] tejże, Studia i szkice o cenzurze w Polsce Ludowej w latach 40. i 50. XX wieku, Wydawnictwo UwB, Białystok, 2014, s. 95-106.

Cieśla A.B., Mania - cenzorka z Ryk; http://www.ryki-dawniej.com/yewish-ryki/zidez-ryk-ve-svete/mania---cenzorka-z-ryk?tmpl=\%2Fsystem\%2Fapp\%2Ftemplates\%2Fprint\%2F\&showPrintDialog=1 (dostęp 31.01.2020).

Ciołkosz A., Wanda Wasilewska. Dwa szkice biograficzne, Polonia Book Fund, Londyn 1977.

Forma M., Wanda Wasilewska jako autorka literatury adresowanej do dzieci i młodzieży, „Zbliżenia Cywilizacyjne” 2016, z. 4, s. 60-77.

Gieba K., Próba epopei. O narracjach założycielskich tzw. Ziem Odzyskanych, „Teksty Drugie" 2015, z. 5, s. 321-335.

Koper S., Kobiety władzy PRL, Wydawnictwo Czerwone i Czarne, Warszawa 2012.

Kuczawa J., Bumerang stalinowskiej laureatki, „Orzeł Biały” [Londyn] 1952, nr 31/32, s. 6-7; nr 34, s. 4-5.

Malenkow G. M., Referat sprawozdawczy na XIX Zjeździe Partii o działalności KC WKP(b), KiW, Warszawa 1952.

Markiewicz H., O typowości w literaturze. Z historii problemu, „Pamiętnik Literacki” 1957, z. 1 (48), s. 46-82.

Matuszewski R., Trylogia Wasilewskiej, „Nowa Kultura” 18.05.1952, nr 20, s. 2, 11. Mrozik A., Komunistki i duch transgresji. „Przypadek” Wandy Wasilewskiej, „Teksty Drugie" 2013, z. 3, s. 11-35.

Mrozik A., „Komuniści (nie) mają ojczyzny..." Wanda Wasilewska jako polska (anty) 
bohaterka narodowa, „Studia Litteraria et Historica” 2013, z. 2, s. 528-554.

Nałęcz D., Główny Urząd Kontroli Prasy 1945-1949, seria: Dokumenty do Dziejów PRL, z. 6, Instytut Studiów Politycznych PAN, Warszawa 1994.

Oświadczenie Rządu RP, „Nowiny Rzeszowskie” 1-2.03.1952, nr 53, s. 1.

Polak M., Wanda Wasilewska o Katyniu. Przyczynek do poczty renegatów polskich II Wojny Światowej, „Mars. Problematyka i historia wojskowości. Studia i materiały" 2002, t. 12, s. 145-154.

Putrament J., Idea staje się życiem, „Nowa Kultura” 5.10.1952, nr 40, s. 1-2.

Putrament J., Wanda Wasilewska i rewolucyjny nurt literatury polskiej, [w:] tegoż, Na literackim froncie, Warszawa 1953, s. 9-15.

Redlich S., Na rozdrożu. Żydzi w powojennej Łodzi 1945-1950, Wydawnictwo IPN, Łódź 2012.

Salwa-Syzdek E., Działalność Wandy Wasilewskiej w latach drugiej wojny światowej, Wydawnictwo MON, Warszawa 1981.

Shore M., Kawior i popiół. Życie i śmierć pokolenia oczarowanych i rozczarowanych marksizmem, Świat Książki, Warszawa 2008.

Syzdek E., W jednym życiu tak wiele... Opowieść o Wandzie Wasilewskiej, Młodzieżowa Agencja Wydawnicza, Warszawa 1980.

Szydłowska J., Narracje pojałtańskiego Okcydentu. Literatura polska wobec pogranicza na przykładzie Warmii i Mazur (1945-1989), Wydawnictwo UWM, Olsztyn 2013.

Tomasik W., Słowo o socrealizmie. Szkice, Wydawnictwo Wyższej Szkoły Pedagogicznej w Bydgoszczy, Bydgoszcz 1993.

Wanda Wasilewska we wspomnieniach, wybór, wstęp i oprac. E. Salwa-Syzdek, KiW, Warszawa 1982.

Wasilewska W., Mord w Katyniu, [w:] Prawda o Katyniu, Związek Patriotów Polskich w ZSRR, Moskwa 1944, s. 5-7.

Wasilewska W., Pieśń nad wodami, cz. 3: Rzeki płoną, Wydawnictwo MON, Warszawa 1952; wyd. 2: tamże 1953, wyd. 3: tamże 1953; PIW, Warszawa 1954; Państwowe Wydawnictwo Literatury Pięknej, Wilno 1955; Wydawnictwo MON, Warszawa 1956 (seria Pisma zebrane, t. 4).

Wasilewski Z., O powieściach Wandy Wasilewskiej, „Życie Literackie” 3.02.1952, nr 3, s. 4-5.

Wasilewski Z., Pierwsza powieść o Pierwszej Armii, „Życie Literackie” 1952, nr 11 25.05.1952, s. 10-15.

Wasilewski Z., Wieś w jarzmie. O powieściach Wandy Wasilewskiej, „Życie Literac- 
kie" 30.03.1952, nr 7, s. 3, 7.

Wiśniewska-Grabarczyk A., Bulletins of the Polish censorship office from 1945 to 1956. A reconnaissance study, „Acta Universitatis Lodziensis. Folia Litteraria PoIonica" 2019, issue 4, s. 311-331.

Wiśniewska-Grabarczyk A., "Czytelnik" ocenzurowany. Literatura w kryptotekstach - recenzjach cenzorskich okresu stalinizmu (na materiale GUKPPiW z 1950 roku), Wydawnictwo IPN, Warszawa 2018.

Wiśniewska-Grabarczyk A., „O wyższy poziom pracy nad książką" - biuletyny urzędu cenzury z lat 1945-1956 w perspektywie literaturoznawczej. Rekonesans, [w:] Cenzura w PRL. Analiza zjawiska, red. Z. Romek, K. Kamińska-Chełminiak, Oficyna Wydawnicza ASPRA-JR, Warszawa 2017, s. 61-74.

Wiśniewska-Grabarczyk A., Segment streszczający recenzji cenzorskiej (na materiale GUKPPiW z roku 1950), „Socjolingwistyka” 2016, z. 1 (30), s. 277-288.

Wiśniewska-Grabarczyk A., The censorship review in the Polish People's Republic as cryptotext, "The Polish Review” 2019, vol. 64, no. 1, s. 37-40.

Woźniak-Łabieniec M., Rytuał w zwierciadle cenzury. Urząd Kontroli jako strażnik kultowego obrazu władzy w początkach Polski Ludowej, „Napis. Pismo poświęcone literaturze okolicznościowej i użytkowej" 2010, seria 16, s. 377-379.

Zatorska H., Wanda Wasilewska, WSiP, Warszawa 1976.

Zawadzka J. [J. Z.], Matuszewski Ryszard, [w:] Współcześni polscy pisarze i badacze literatury. Słownik biobibliograficzny, t. 5: L-M, pod red. J. Czachowskiej, A. Szatagan, WSiP, Warszawa 1997, s. 327-331.

XIX Zjazd KPZR. O sprawach kultury i sztuki, „Życie Literackie” 26.10.1952, nr 22, s. $2,15$. 